WARSZTATY Z GEOGRAFII TURYZMU

ISBN 978-83-7969-138-8 $\quad$ s. 189-206

http://dx.doi.org/10.18778/7969-138-8.13

Maciej GUZ

Uniwersytet Łódzki

\title{
TWÓRCY LUDOWI O KOMERCJALIZACJI KULTURY LUDOWEJ NA POTRZEBY RYNKU TURYSTYCZNEGO: PRZYKŁAD ZIEMI ŁOWICKIEJ
}

\section{Wstęp}

Kultura ludowa w Polsce uległa znaczącym przemianom na przestrzeni wieków. Wydaje się, że dawno już zatraciła pierwotną funkcję - nie jest już tylko lokalna i nie służy zaspokajaniu potrzeb niewielkich społeczności. Współcześnie obserwuje się intensywną komercjalizację jej elementów. Łowickie dobrze ilustruje ten proces. Jest to obszar odwiedzany przez turystów, gdzie ruch turystyczny generują zabytki architektury, mazowiecki krajobraz wsi, dziedzictwo kulturowe w postaci tradycji, zwyczajów i folkloru. Rejon ten wyróżnia się strojem ludowym, muzeami i skansenami sztuki ludowej. Kultura ludowa stała się tu produktem turystycznym i stanowi swoisty towar eksportowy nie tylko ziemi łowickiej, ale i kraju.

Artykuł przedstawia historyczne ujęcie komercjalizacji, jej wpływ na działalność łowickich twórców ludowych i stanowi próbę odpowiedzi na pytania: w których aspektach współczesnej twórczości ludowej zaznacza się komercjalizacja i jakie są jej efekty? Analizie poddano motywy i sens tworzenia, formułę przekazu profesji artystycznej, warsztat i proces twórczy oraz zdefiniowano odbiorców sztuki ludowej, by w konsekwencji ocenić oryginalność współczesnego rękodzieła ludowego i wskazać na atrybuty autentycznego twórcy ludowego. 


\section{Materiał i metoda badawcza}

Obszar badawczy stanowi Księstwo Łowickie w granicach administracyjnych powiatu łowickiego ${ }^{1}$ (rys. 1). Metodą kuli śnieżnej (BABBIE 2008) dobrano respondentów - czynnych twórców ludowych - do badania o charakterze jakościowym (SILVERMAN 2009). Posłużono się techniką wywiadu swobodnego ukierunkowanego² (PRZYBYŁOWSKA 1978; inaczej pogłębionym wywiadem etnograficznym - KONECKI 2000). Narzędzie stanowił scenariusz wywiadu z listą pytań (i dyspozycjami; zał. 1). Odpowiedzi respondentów rejestrowano ${ }^{3}$, a transkrypcje z wywiadów miały postać dosłownego zapisu.

W III kwartale 2010 r. przeprowadzono 12 wywiadów z twórczyniami ludowymi. Wszystkie odbyły się w miejscu ich zamieszkania: cztery w Łowiczu, dwie w Boczkach, a pozostałe w Bobrownikach, Zdunach, Różycach, Zabostowie Małym, Osieku I i Rząśnie (rys. 1). Średni wiek badanych to 66 lat (45-86). Respondentki deklarowały pozostawanie w związku małżeńskim (sześć osób) lub były wdowami (sześć). Wszystkie miały dzieci. Badane twórczynie deklarowały się wykształceniem średnim i zawodowym (po dwie osoby), podstawowym (sześć) i niepełnym podstawowym (dwie). Dwie twórczynie specjalizowały się $\mathrm{w}$ bibułkarstwie, cztery $\mathrm{w}$ hafcie, a pozostałe w wycinance, rzeźbie oraz poezji i malarstwie. Średnia długość wywiadu wyniosła 32 minuty i 41 sekund (16 minut i 7 sekund - 53 minuty i 25 sekund). Wywiady przebiegały bez zakłóceń (według scenariusza; zał. 1).

\section{Rys historyczny i kultura ludowa ziemi łowickiej}

Historia ziemi łowickiej jest związana z dziejami Mazowsza i osobliwym rozwojem administracyjno-gospodarczym Łowicza. Źródła nie podają kon-

${ }^{1}$ W powiecie łowickim koncentruje się 82,6\% walorów krajoznawczych tradycyjnej łowickiej kultury ludowej (za RoGALEWSKIM 1974), 51,5\% bazy gastronomicznej i 52,8\% bazy noclegowej zlokalizowanych w granicach dawnego Księstwa (GUZ 2011a). Zamieszkuje tu 79,7\% wszystkich łowickich twórców ludowych (GUZ 2011b).

2 Twórcy ludowi są specyficzną grupą, m.in. ze względu na (intuicyjnie domniemane przez autora) cechy społeczno-demograficzne, np. niepełne wykształcenie czy podeszły wiek. Forma swobodnej wypowiedzi jest $\mathrm{w}$ tym przypadku bardziej informatywna (bo i bardziej zrozumiała dla respondenta) niż wywiad standaryzowany.

${ }^{3}$ Zgodnie $\mathrm{z}$ zasadami etyki poinformowano respondentów o nagrywaniu audio wywiadów (BABBIE 2008). 
kretnej daty przekazania terenów wokół miasta władzom kościelnym, ale musiało to mieć miejsce przed 1136 r., z którego pochodzi tzw. bulla gnieźnieńska potwierdzająca ich nadanie arcybiskupom i lokację miasta. Korzyści ówczesnego prawa i kościelna jurysdykcja pozwalały na prężny rozwój regionu (SMOLARSKI 1953, KOŁODZIEJCZYK 1986). Nowo zakładane wsie miały sołtysów, a osadnicy objęci tzw. wolnizną dostawali w dziedziczne użytkowanie ziemię immunizowaną (zwolnioną ze świadczeń). Przywileje kościelne z XVI i XVII w. pozwalały chłopom - po uregulowaniu "rent" - cieszyć się wolnością i pomnażać bogactwo (SKIEŁCZYŃSKI 1995). W 1815 r. dobra łowickie przeszły $\mathrm{w}$ ręce carów rosyjskich - najpierw Mikołaja I, potem Konstantego, którego żona przybrała tytuł księżnej łowickiej. Akt tego nadania był pierwszym dokumentem potwierdzającym nazwę Księstwa ${ }^{4}$ i jego mieszkańców - Księżaków. Łowickie było wówczas obszarem obsługi rolnictwa (KOŁODZIEJCZYK 1986). Po 1945 r. w konsekwencji zmian społeczno-gospodarczych Łowicz stopniowo przekształcił się z ośrodka rolniczo-rzemieślniczego w centrum przemysłowo-rolne i miasto turystyczne ${ }^{5}$.

Specyfika ziemi łowickiej w rozumieniu regionu etnograficznego, tj. przestrzeni, w której występują określone zjawiska kulturowe (BARTMIŃSKI 1990, BRENCZ 1996), wyraża się w materialnych, społecznych i duchowych faktach łowickiej kultury ludowej (GAJEK 1976, BURSZTA 2000). Elementy wyróżniające łowickie na tle innych regionów etnograficznych to:

- ubiory - pasiaki - ewoluujące kolorystycznie od ciemnoczerwonych pasów z czarnymi lub białymi prążkami (w początkach XIX w.), przez barwy: zieloną, żółtą i granatową na jednobarwnym tle, po wszystkie kolory tęczy (w końcu XIX w.), oraz bogato zdobione ręcznym haftem płaskim, krzyżykowym i koralikowym, z motywami kwiatowymi;

- domy, ich umeblowanie i dekoracja - kryte słomą drewniane chałupy z izbami: świąteczną („,białą") i roboczą („,czarną"), malowane na niebiesko, z białymi wzorami roślinnymi i geometrycznymi, wyposażone w (zdobione snycerką) skrzynie, kredensy, ławy, domowe ołtarzyki,

${ }^{4}$ Księstwo Łowickie jest nazwą zwyczajową (nie księstwem w pełnym tego słowa znaczeniu) i funkcjonuje w odniesieniu do granic dawnej kasztelanii łowickiej. Jest niesłusznie utożsamiane wyłącznie z obecnym powiatem łowickim, bo obejmuje też wschodnią część powiatu skierniewickiego, zachodnie krańce powiatu brzezińskiego i północne części powiatu tomaszowskiego w województwie łódzkim (KOŁODZIEJCZYK 1986, SKIEŁCZYŃSKI 1995).

5 Badania ruchu turystycznego w województwie łódzkim (KACZMAREK, STASIAK, WŁODARCZYK 2005, WŁODARCZYK 2011) i badania własne autora (GUZ 2009, 2011b) pokazują, że łowickie koncentruje krajoznawczy ruch turystyczny o zasięgu ponadregionalnym, gdzie dominują pobyty jednodniowe odwiedzających i przejazdy tranzytowe. 
eksponowane łóżka i dekorowane wycinankami, pająkami czy kwiatami z bibuły;

- zwyczaje, obrzędy i towarzyszące im wierzenia - m.in. Boże Narodzenie, święto Matki Boskiej Gromnicznej, Trzech Króli, św. Błażeja i św. Agaty, ostatki i „półpoście”, Wielkanoc, Zielone Świątki, święto Bożego Ciała, Noc Świętojańska, święto Matki Boskiej Zielnej, zbiór kartofli, pocieranie lnu, darcie pierza, zwyczaje rodzinne (m.in. chrzciny i wesela) ${ }^{6}$.

Dawne Księstwo zamieszkuje obecnie 79 czynnych twórców: 63 w powiecie łowickim i 16 w skierniewickim (BARTOSIEWICZ, SŁOMSKA 2007). W pier-wszym z nich zdefiniowano siedem dziedzin twórczości (rys. 1.). W gminie Kocierzew Południowy mieszka 16 twórców: 11 zajmuje się haftem (wsie: Wejsce, Osiek, Różyce, Kocierzew Południowy, Boczki), cztery osoby wycinanką (Boczki) i jedna rzeźbą (Sromów). Twórcy z gminy Zduny reprezentują: haft - pięć osób (Rząśno, Zduny, Strugienice, Wierznowice, Jackowice), wycinankę - cztery (Niespusza) i rzeźbę - dwie (Zduny). W gminie Chąśno działają: cztery hafciarki (Chąśno, Goleńsko) oraz poetka, wycinankarka i osoba robiąca ozdoby z bibuły (Chąśno, Błędów, Goleńsko).

W gminie wiejskiej Łowicz twórcy zajmują się: haftem - dwie osoby (Pilaszków, Zielkowice), bibułkarstwem - dwie (Zielkowice), wycinanką - jedna (Zabostów Duży) i rzeźbą - jedna (Zabostów Mały; rys. 1). Dwóch twórców z gminy Nieborów reprezentuje bibułkarstwo (Bobrowniki) i rzeźbę (Nieborów). Co trzeci twórca (21 osób) z badanego obszaru mieszka w Łowiczu. Wycinanką i haftem zajmuje się tu po osiem osób, a koronkarstwem i bibułkarstwem - po dwie. Jedna twórczyni to poetka i malarka. W gminach Domaniewice i Łyszkowice nie ma twórców. Pozostałe 16 osób to mieszkańcy powiatu skierniewickiego - przedstawiciele rzeźby, garncarstwa, wycinanki, haftu i koronkarstwa.

Respondentki zgodnie twierdziły, że w porównaniu z okresami ich młodości obecnie jest więcej łowickich twórców. Nie są to jednak autentyczni twórcy ludowi, co zauważa jedna z badanych rzeźbiarek, podając, iż:

twórców ludowych, takich z krwi i kości, prawdziwych, to jest mniej. Teraz jest więcej osób, które robią rzeczy z motywem ludowym, właśnie na sprzedaż.

${ }^{6}$ Nie ma tu miejsca na szczegółowy opis regionalnych zwyczajów, stąd autor zachęca do lektury A. CHMIELIŃSKIEJ (1935) oraz A. i H. ŚWIĄTKOWSKICH (1996), którzy szeroko pisali o obrzędach i wierzeniach w Księstwie Łowickim. 
Wynikać to może z pewnej „mody na ludowość”, gdyż, jak dodaje respondentka:

Twórczość ludowa była, gdzieś tam cichutko ona sobie była, nie? Może to nie było tak rozreklamowane, rozpropagowane.

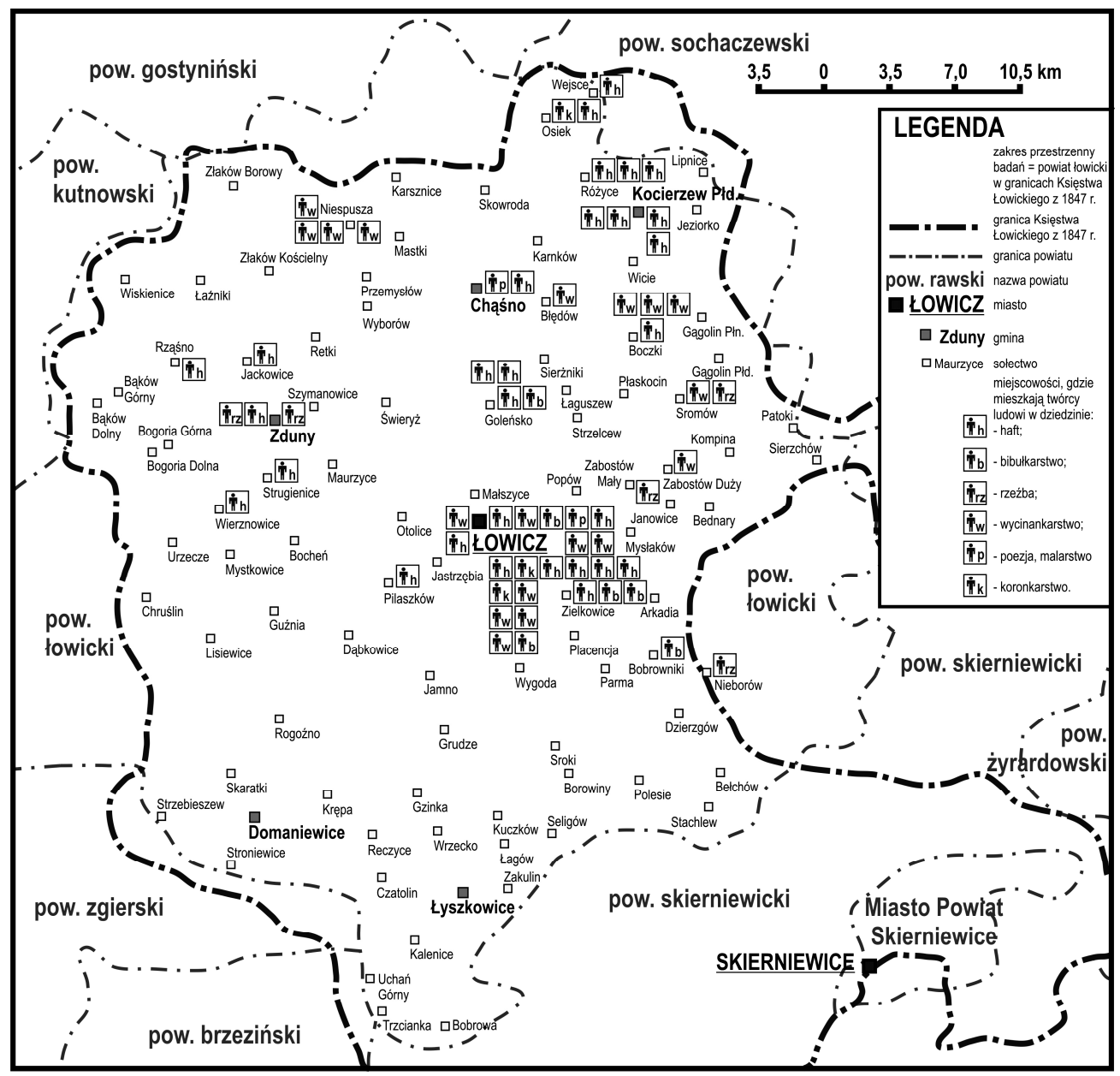

Rys. 1. Czynni twórcy ludowi na badanym obszarze według profesji Źródło: opracowanie własne na podstawie mapy Powiat towicki. Mapa turystyczna w skali 1: 75000 (2006) oraz M. BARTOSIEWICZ, J. SŁOMSKA (2007) i badań własnych 


\section{Wymiary komercjalizacji łowickiej kultury ludowej}

Komercjalizację kultury rozumie się ,jako tendencję do dominacji tych dóbr kultury, które przynoszą duży zysk twórcom i pośrednikom będącym główną pobudką tworzenia i obiegu. Komercjalizacja nie przesądza z góry o charakterze owych dóbr [...], o ich poziomie artystycznym i intelektualnym, o ich zawartości światopoglądowej”, ale sprawia „że wszystko to, co może przynieść duży zysk, będzie w obiegu [...] jeżeli tylko ujawni się masowe nim zainteresowanie" (GOLKA 1992), co może czynić ją zjawiskiem niekorzystnym. Podobnie wypowiadają się też DZIAMSKI (1992) i KURELLA (1992), wskazując na infantylizację wytworów kultury (wywołaną zaspokajaniem masowych potrzeb i urynkowieniem kultury w ogóle). Na swoistą naturalność tego procesu uwagę zwróciły A. KŁOSKOWSKA (1992) i K. MILCZAREK (1997).

Podstaw komercji upatrywać należy w symbolicznym sensie istnienia kultury, która ,jakkolwiek należy do sfery idei bezcielesnych i długowiecznych, musi być tworzona $\mathrm{w}$ fizycznej postaci i rozpowszechniana. A to wszystko musi mieć podstawy w twardych materialnych, ekonomicznych czynnikach" (KŁOSKOWSKA 1992). Cytowana autorka wymienia tu mecenat, politykę kulturalną i rynek oraz podkreśla, że w warunkach polskich miało miejsce przejście raczej od mecenatu do systemu komercyjnego niż do polityki kulturalnej. Był to tzw. okres pośredni (MILCZAREK 1997), powodowany niestabilną sytuacją polityczną, głównie zaborami i brakiem własnego państwa, co skutecznie uniemożliwiało rozwój polskiej (państwowej) polityki kulturalnej.

W związku z powyższym uzasadnione wydaje się podejście do problemu komercjalizacji w polskiej kulturze ludowej z charakterystyką jej funkcjonowania w dwóch zasadniczo różniących się okresach, tj. w warunkach kultury centralnie sterowanej i sytuacji kulturalnego policentryzmu. W okresie PRL miało miejsce tzw. zamawianie rękodzieła ludowego i jego sprzedaż z wcześniej skalkulowanym zyskiem. Była to komercjalizacja „w czystej formie”, bo sprowadzała twórczość do działalności stricte gospodarczej. Jej kształt wyznaczała działalność Centrali Przemysłu Ludowego i Artystycznego (Cepelii7), komisji Ministerstwa Kultury i Sztuki (MKiS) oraz Stowarzy-

7 Cepelia powstała w 1949 r. wnioskiem MKiS i Biura Nadzoru Estetyki Produkcji celem skupienia rozproszonej w różnych organizacjach twórczości ludowej i sprawowania państwowej opieki nad twórcami. Jej skład to: spółdzielnie rękodzieła ludowego i artystycznego, zakłady przemysłu 
szenia Twórców Ludowych (STL8; KURELLA 1992), których członkiniami była lub jest większość badanych twórczyń. Koniunktura w przemyśle rękodzielniczym wiązała się jednak $\mathrm{z}$ masowością i zanikiem autentyczności ludowych wyrobów. Środowisko wiejskie zostało pozbawione "duchowości", gdyż ówczesne władze popularyzowały te elementy kultury ludowej, które wpisywały się w propagandowy obraz wsi, a sama kultura ludowa stała się narzędziem legitymizacji władzy (MOKRAS-GRABOWSKA 2009). Z drugiej strony rejestracja w Cepelii lub STL była dla twórców po prostu opłacalna: gwarantowała zbyt na rękodzieło, dochód i świadczenia socjalne, np. ubezpieczenie społeczne, prawo do dwutygodniowego „urlopu twórczego" i tzw. "dodatkowej powierzchni” mieszkania. Ponadto Cepelia - jako mecenat spółdzielczo-państwowy - zdefiniowała nową grupę zawodową w ramach twórców nieprofesjonalnych, tj. twórców ludowych, których miała cechować samodzielna twórczość oparta na regionalnych tradycjach i wykształcenie (a raczej jego brak; KURELLA 1992), o czym wspominała jedna z łowickich wycinankarek:

Powiedziano mi, że mam wykształcenie niezbyt jak na twórcę ludowego. Mam studium nauczycielskie. Nie chcą mnie tam i już. Tam są osoby, które raczej nie mają żadnego [...]. Oni sobie tak życzą.

Jak zauważa DZIAMSKI (1992), przemiany ustrojowe w Polsce po 1989 r. polegały m.in. na wprowadzeniu rynku konsumenta w miejsce rynku producenta (czy rynku niedoboru) także w obszarze kultury (w tym kultury ludowej). $Z$ jednej strony nowa epoka dała możliwości spotykania się w większym gronie, co podkreślała jedna $\mathrm{z}$ badanych rzeźbiarek:

każdy twórca, który chce wyjść ze swojego podwórka naprawdę w tym czasie ma ogromne możliwości.

artystycznego, magazyny hurtowe, punkty skupu towarów i sklepy detaliczne, gdzie rękodzieła dostarczało w okresie największej świetności ok. 200 tys. osób. W 1990 r. przeprowadzono procedurę upadłościową Cepelii i powstały: Izba Gospodarcza Rękodzieła Ludowego i Artystycznego, Fundacja Cepelia Polska Sztuka i Rękodzieło, Cepelia Polska Sztuka i Rękodzieło sp. z o.o., Spółdzielczy Związek Rewizyjny Cepelia i Cepelia Tourist sp. z o.o. (na podstawie www.cepelia.pl).

8 STL powstało z inicjatywy twórców ludowych w 1968 r. w Lublinie. Obecnie zrzesza ok. 2 tys. osób. Jego celem jest kultywowanie tradycji kultury ludowej: plastyki, folkloru i literatury ludowej, popularyzacja przejawów artystycznej twórczości ludowej, roztaczanie opieki nad twórcami, ich reprezentacja, zbiorowe zarządzanie, ochrona powierzonych praw autorskich lub pokrewnych (na podstawie www.zgstl.pl). Członkiem STL może „zostać pełnoletni obywatel Polski, który tworzy w dziedzinie sztuki ludowej, pisarstwa ludowego, muzyki, tańca, o ile: a) zgłosił Zarządowi Głównemu przystąpienie lub przyjął [jego] propozycję przystąpienia; b) o autentyzmie jego twórczości orzekła Rada Naukowa STL poprzez specjalistyczną sekcję, w oparciu o dostarczone prace lub orzeczenie kompetentnych instytucji" (KURELLA 1992). 
Społeczne kontakty poszerzyły się poprzez warsztaty, wystawy rękodzieła, oddolne inicjatywy: lokalne organizacje, stowarzyszenia i zrzeszenia twórców ludowych, w których aktywny udział deklarowały wszystkie respondentki. Dla większości badanych jest to zjawisko pozytywne, świadczące głównie o otwartości środowiska twórców, choć pojawiły się też wskazania na „,niezdrowe” relacje w tym gronie, m.in.:

Jest zazdrość okropna pomiędzy tu nami, bo muszę powiedzieć, że to mnie nieraz jest przykro. Zazdrość, żebym się nie wzbogaciła, bo to komuś się wydaje, że na tym to się zarobi. A na tym to się nie zarobi tak dużo [wycinankarka z Łowicza].

Z drugiej strony wolny rynek umożliwił dynamiczny rozwój branży turystycznej, a ta nie pozostała bez wpływu na kulturę ludową. Proces komercjalizacji kultury ludowej na potrzeby rynku turystycznego przedstawiła J. MOKRAS-GRABOWSKA (2009) pisząc, że „w obecnym środowisku wiejskim kultura ludowa funkcjonuje $\mathrm{w}$ postaci reliktów kultury dawnej, kultury ludowej dawnej uwspółcześnionej, bądź kultury ludowej o charakterze komercyjnym". Ostatnia z wymienionych, rozpoznana przez turystów w formie zasobów, przekształca się $\mathrm{w}$ walory turystyczne, następnie $\mathrm{w}$ atrakcje i produkt turystyczny o dwojakiej postaci, tj. autentyczny (,zgodny z dawną tradycją") i/lub nieautentyczny, który ma jedynie „spełniać oczekiwania turystów [...], stanowić pamiątkę z regionu".

Poetka i malarka z Łowicza stwierdziła tu:

Niech sam nawet Pan popatrzy na Łowicz: ile gadżetów jest, ile jest na przykład haftów wprowadzanych na ubrania, na odzież, na krawaty, na koszulki.

Na terenie ziemi łowickiej funkcjonują produkty turystyczne (za definicją KACZMARKA, STASIAKA, WŁODARCZYKA 2005), bazujące na kulturze ludowej (m.in. jarmarki rękodzieła, towarzyszące im imprezy folklorystyczne, muzea i skanseny, zespoły ludowe, karczmy regionalne), i są głównym celem turystycznych odwiedzin regionu (GUZ 2011b). W przestrzeni kultura ludowa pojawia się też w innych (zauważalnych przez mieszkańców i turystów) formach, takich jak: tablice rejestracyjne samochodów, środki komunikacji miejskiej, drogowskazy. Modelowym przykładem komercji jest, cieszący się dużym zainteresowaniem odwiedzających, łowicki przemysł pamiątkarski (GuZ 2011b). Warto nadmienić, że turystyczną wizytówką regionu są obchody Bożego Ciała, a nawiązanie do ludowości są stałym punktem promocji Łowicza i kraju w skali międzynarodowej. 


\section{Współczesna łowicka twórczość ludowa}

Obecną działalność twórców warto odnieść do cech klasycznej kultury ludowej: izolacjonizmu, tradycjonalizmu, ustnej formy przekazu wiedzy i tradycji, sensualizmu oraz specyficznego typu religijności (BURSZTA 2000). Na poziomie deklaracji sens twórczości ma podłoże $\mathrm{w}$ zaspokojeniu potrzeb samorealizacji i najczęściej jest zachowaniem wolnoczasowym, o czym świadczą słowa respondentek, m.in.:

To jest tak przyjemna rzecz, że to takie inne wrota się otwierają w człowieku. Jest cisza, spokój, nie ma kłopotów, nie ma problemów. Inny świat [poetka i malarka z Łowicza].

Twórca nie ma zamówienia, nie ma pracy zleconej, a mimo wszystko robi to, bo to jest jego wewnętrzną potrzebą [rzeźbiarka z Zabostowa M.].

Ja to kocham i robię [hafciarka z Różyc].

Respondentki wskazywały, że do pracy artystycznej inspiracją jest głównie przyroda (próba odtworzenia otaczającego świata) oraz motywy religijne, życie codzienne, praca na roli, ludowe zwyczaje i obrzędy. Zaobserwowano tu dwie zasady wyznaczające cykliczność tworzenia. Pierwsza to pory roku (,rytm przyrody”), dyktujące pracę na roli:

Człowiek żyje w rytmie natury, w tym klimacie wsi. [...] czas intensywnych prac w polu to te prace rzeźbiarskie czy inne, troszeczkę muszą iść na bok [rzeźbiarka z Zabostowa M.].

W zimie [...] to się wtedy człowiek nie spieszy nigdzie [rzeźbiarka ze Zdun].

No, latem już mniej, bo jednak gospodarstwo jest, prace polowe [wycinankarka z Boczek].

No, zimową porą jest więcej [...]. Dzisiaj troszkę pogody jest już, to jest robota w polu. Taka jest wieś. Całą nocą kombajny młócą [hafciarka z Osieka].

Jedna z rzeźbiarek wskazała też na istotę rytmu świąt:

Nie ma się tu co oszukiwać. Święta są też tu dużym impulsem, no nie, żeby tworzyć, nie? Adwent, to już człowiek myśli [...] szopkę bożonarodzeniową i tak dalej. Święta Wielkanocne, to wiadomo, nie? No jest człowiek nastrojony, przynajmniej ja, na rzeczy, takie związane z Panem Jezusem, ukrzyżowaniem i tak dalej,

a respondentka z Bobrownik zajmująca się bibułkarstwem dodała, że tworzenie: 
związane jest $\mathrm{z}$ obrzędami ludowymi. Luty, marzec chodzimy na ostatki z misiem. O chodzeniu $z$ turoniem - tak to ujęli w swojej książce Świątkowscy - jest nazwa chodzenia z misiem. Mamy też zespół ludowy. Wystawiamy z nim jasełka na Boże Narodzenie. Poza tym obrzęd pasania gęsi. Jest to opowiadane gwarą.

Respondentki biorą też udział w konkursach dla twórców i mają osiągnięcia, czym chwaliły się m.in. hafciarka z Różyc:

Grand Prix - mój sukces najważniejszy. Ten strój robiłam dla Ojca Świętego, jak był w Łowiczu.

I wycinankarka z Łowicza:

W Łodzi w Domu Kultury mi wręczano jedną z pierwszych nagród [...] mieliśmy wystawę: „Pamiątka z Polski”. Do Ameryki pojechały wycinanki. I moje też.

Poczesne miejsce $\mathrm{w}$ zbiorach zajmują właśnie prace nagrodzone oraz wymagające dużego nakładu sił i czasu. Jest to rękodzieło nie na sprzedaż i nierzadko bezcenne dziedzictwo regionalne, o czym wspomniała m.in. rzeźbiarka z Zabostowa M.:

Wiedziałam jedno: jak do prywatnych kolekcjonerów, to rozejdą się gdzieś daleko w świat. Albo są u mnie, albo w muzeum, [...] są w miejscu tworzenia, gdzie się człowiek urodzit.

Twórczość badanych kształtowały trzy rodzaje „ścieżek":

1) przekaz rodzinny - w rodzinie respondentek byli twórcy ludowi:

Dziadziuś grał na skrzypcach. Babcia miała krosna. My tkałyśmy te tkaniny na pościel i koszule. Mama moja przędła len, przędła wełnę. Ja się chowałam przy tym [hafciarka z Osieka].

Mój ojciec był bardzo utalentowany. Wiersze, to jak z rękawa, jeden za drugim. A z manualnych [...], też malował pięknie [malarka i poetka z Łowicza].

Jak mama robiła, to się pomagało. Nici trzeba było podawać, puchy. To od maleńka człowiek pomagał. Później wyszywać, to tak samo, bo mama wełnę przędła, bo się owce trzymało" [hafciarka z Boczek];

2) przekaz pozarodzinny - $w$ rodzinach badanych osób nie było twórców; fachu uczyli się od postronnych osób, jak np. respondentka z Bobrownik: „Nauczyłam się robić kwiaty na warsztatach bibułkarskich w Skierniewicach";

3) typ samouka: 
Widziałam, podpatrzyłam i sama się tego nauczyłam [hafciarka z Różyc].

Uczyłam się sama, bo w domu, to nikt. Znalazłam jakieś szczątki wycinanek na strychu jeszcze w starym mieszkaniu, ale nie wiem skąd to było, bo babcia już nie żyła" [wycinankarka z Boczek].

Moja mama robiła wycinanki. I tata. I pająki robili. Ale my z siostrą lewe. W ogóle nie miałyśmy do tego ochoty. Ale ja te kwiaty to tak, taki samouk [respondentka z Łowicza, robiąca ozdoby z bibuły].

Nigdy nikt nie rzeźbił. Ojciec zimą dorabiał w stolarni. Z drewnem obcowałam już jako mała dziewczynka. Natomiast potem dziecko rośnie, obserwuje, ma tą świadomość większą, mniejszą. No i zaczęłam sobie tak zwyczajnie strugać różne tam zabawki, nie? [rzeźbiarka z Zabostowa M.].

Badane twórczynie wskazały na swoich potencjalnych następców:

- dzieci/wnuki/prawnuki:

Najmłodsza wnuczka pisze wierszem. Mój wnuczek pięknie maluje [malarka, poetka $z$ Łowicza].

Wnuczki wszystkie haftują koralikami, a ta we średnia haftuje maszynowo [hafciarka z Boczek].

Myślę, że u mnie w domu dzieciaki mają te predyspozycje do tego, ponieważ obcują z tym, oddychają tym od samego początku, od samego urodzenia. Patrzą, próbują" [rzeźbiarka z Zabostowa M.];

- uczestników warsztatów:

Mieliśmy warsztaty w muzeum [...] wycieczki przyjeżdżały i dzieci się uczyły [wycinankarka z Łowicza].

Respondentki tworzą głównie w domach, gdzie mają „swój kącik”, jak m.in. poetka i malarka z Łowicza:

Dom rodzinny to jest miejsce mojej mocy. Tam mi wszystko do głowy przychodzi

i odpowiednio wyposażoną przestrzeń, o czym wspomniała hafciarka z Osieka:

Warsztat to musi być osobny, bo i wzory, i żelazko musi być, i mulina.

Nieliczne badane twórczynie nie utożsamiają pracy z konkretnym miejscem:

Ulubionym warsztatem pracy to jest dwór. Dla twórcy rzeźbiarza to wystarczy kawałek drewna, siekierka i jakieś tam narzędzia. I nie potrzeba wielkich funduszy [rzeźbiarka z Zabostowa M.]. 
Warsztat mogę przynieść tutaj. To nie jest jakieś tam miejsce [hafciarka z Łowicza].

Innym sytuacja rodzinna i warunki mieszkaniowe nie pozwalają na posiadanie warsztatu:

Nie mam swojego miejsca. Kiedyś myślałam, że będę miała swoją, nawet najmniejszą pracownię, no niestety. Córka tutaj mieszka. No tak jest. Nie ma się co tutaj spowiadać [wycinankarka z Łowicza].

Wśród odbiorców rękodzieła rozróżniono odbiorców 1) legalnych bezpośrednich - nabywających je w bezpośrednim kontakcie $\mathrm{z}$ twórcami (często na zamówienie), instytucje kultury (muzea, lokalne ośrodki kultury) i osoby z otoczenia twórców (rodzina/znajomi); 2) legalnych pośrednich - odwiedzający - nabywający rękodzieło w postaci pamiątki turystycznej, 3) nielegalnych („niechcianych”) - kradnących wzory (np. wycinanek lub haftów).

Brak ochrony własności w tej dziedzinie ${ }^{9}$ skutkuje, m.in. następującymi sytuacjami:

Poznałam kiedyś swoją, co wzięli ją na pocztówkę. Na kopercie to umieszczono. No, ale nikt nie chciał mi uwierzyć, bo ja mogłam na przykład prosić o jakąśs zapłatę autorską [wycinankarka z Łowicza].

W Łodzi byłam na kiermaszu i powiedziałam, no, facetowi: skąd pan ma kolczyki? One są z moich wycinanek. Skąd pan je wziął? Głowę spuścił. Nie wiedział, co powiedzieć. No, przecież to są moje wycinanki. No i sprzedaje. Była taka sprawa, że ktoś tam podszył się i pod moje wycinanki w Internecie. I jak to można powiedzieć, że na własnych wzorach się opiera, kiedy to są moje [wycinankarka z Boczek].

Inna łowicka wycinankarka podsumowała ten temat słowami:

Taka jest prawda o tym wszystkim, co robimy [my - twórcy], że nigdy nie wiadomo, gdzie to wszystko trafi.

Twórczynie, choć świadome wspomnianych praktyk, rzadko podejmują walkę na drodze sądowej.

„Druga strona medalu” to zarobkowanie - sprzedaż rękodzieła na kiermaszach i w pobliżu atrakcji turystycznych ${ }^{10}$, o czym badane twórczynie mówią otwarcie, m.in. hafciarka z Osieka:

9 Rozporządzenie MKiS z 1973 r. mówi, że „oryginalne dzieła z zakresu sztuki ludowej były chronione prawem autorskim na równi z dziełami twórców profesjonalnych, ale brak tego zapisu w Prawie Autorskim powodował [...] naruszanie autorskich dóbr" (KURELLA 1992). Z badań wynika, iż wciąż brak tu regulacji prawnych. 
Tyle, co się zarobi właśnie na tych kiermaszach, a respondentka robiąca ozdoby z bibuły z Bobrownik:

Mamy stoisko z kwiatami i pokazujemy, jak się te kwiaty robi. Część kwiatów się sprzedaje oczywiście za jakieś tam drobne pieniążki, czy rzeźbiarka z Zabostowa M.:

To jest czas wspaniały dla twórców [...] możliwość pracy na umowę zlecenie, o dzieło.

Dla badanych osób twórczość ludowa stanowi dodatkową formę zarob$\mathrm{ku}$ (np. jako dodatek do emerytury lub do dochodów z gospodarstwa). Nie jest bowiem możliwe utrzymanie się wyłącznie z twórczości:

$\mathrm{Z}$ tego się nie wyżyje. A innym to się wydaje, że człowiek to nazarabia nie wiadomo ile [hafciarka z Boczek].

Inna ankietowana twórczyni jest zdania, że:

Inaczej robi się dla pieniądza i niektóre osoby to potrafią, a ja na przykład nie [wycinankarka $z$ Łowicza].

Obecna sztuka ludowa nie jest już tą samą, którą respondentki znają z dzieciństwa. Jedne, jak hafciarka z Różyc, twierdziły, że:

Jest gorsza jakościowo, gorsze wykonanie nićmi [...] na ilość, nie na jakość, drugie - przeciwnie, np. bibułkarstwo:

różni się troszeczkę kwiatami. Te kwiaty nie były takie dopracowane [...]. Są bardzo podobne do autentycznych. Nie było kiedyś tak [respondentka z Bobrownik].

W opinii innych:

Wszystko jest po prostu już inaczej. Dawniej to byli pasjonaci [rzeźbiarka z Zabostowa M.],

a wytworów ludowych jest:

teraz mało w takiej starej, oryginalnej formie. Są takie pod współczesność [poetka i malarka z Łowicza].

To na potrzeby rynku turystycznego pojawia się rękodzieło nie-łowickie, łamiące podstawowe zasady twórczości (np. kanon wzorniczy i kolorystyczny).

${ }^{10}$ Na przykład park w Arkadii, zespół pałacowo-parkowy w Nieborowie, skansen w Maurzycach, muzeum w Łowiczu. 
Niech Pan spojrzy. [Respondentka z Bobrownik pokazuje kwiaty z bibuły] To nie jest kompozycja ludowa. To jest na promocję, na handel, na sprzedaż, dla turystów z zagranicy. To nie jest twórczość ludowa.

Przeciętny turysta prawdopodobnie wcale nie szuka oryginalnego rękodzieła. Nie ma też kompetencji i wiedzy, by je rozpoznać, co podkreśla wycinankarka z Łowicza:

Są prace, na które trudno spojrzeć. [...] są ludzie, którzy się na tym nie znają i też kupią,

a jedna z rzeźbiarek dodaje:

I jest ktoś, kto mówi: mnie pamiąteczki nie interesują, ja szukam rzeźby ludowej, autentycznej, która ma ducha, jest autentyczna, nie jest wykonana przez obróbkę komputerową, która rzeczywiście oddaje uczucia, przeżycia prawdziwego twórcy.

Niska jakość i brak oryginalności często wynikają z szablonowej (masowej i szybkiej) „produkcji”. Badane twórczynie mają świadomość stosowania najnowszych technik komputerowych, głównie w wycinankarstwie i hafciarstwie, ale nie popierają takich praktyk. Jedna z rzeźbiarek stwierdziła, że wówczas nie powinno się w ogóle mówić o sztuce, a o pamiątkach turystycznych:

Niektórzy może chcą tyko taką pamiątkę. Nie szukają sztuki. Jest to po prostu pewien rodzaj rzemiosła, który produkuje pamiątkę. Jeżeli ktoś [...] robi, tak jak mówię na wyrzynarce, [...] i jest wycięty łowiczaczek malutki czy może być łowiczanka, to jest też pewna pamiątka z tego regionu, ale nie ma $w$ tym sztuki już. Moje zdanie jest takie: proszę pana spokojnie może funkcjonować pamiąteczka i spokojnie może funkcjonować prawdziwa rzeźba, która naprawdę ma rangę sztuki i jest dużą wartością.

Ponadto respondentki deklarowały, że nie korzystają z gotowych szablonów, rysują autorskie wzory i nie kopiują, a własne wyroby z łatwością są w stanie rozpoznać wśród setek innych (haftów, wycinanek, bibułowych kwiatów itp.).

Większość badanych twórczyń wręcz negowała istnienie autentycznych twórców ludowych współcześnie:

No, było nas z dziesięć twórców. Twórców ludowych. A teraz z pięćdziesiąt jest. To jest twórca? Jest twórców na papierze. I są takie, co tu przyjedzie i chce, żeby jej zrobić na jutro pająk, bo już wyjeżdżo, a nie zdążyła zrobić, a una nic nie zrobiła, tylko pozbiera, wie Pan [hafciarka z Osieka]. 
lub wskazywano na ich bardzo niewielką ilość. Zdaniem jednej z respondentek, nieautentycznych twórców kreuje branża turystyczna:

On [rynek turystyczny] tą twórczość ludową po prostu psuje. Dobrze by było, żeby w tym wszystkim ludzie, którzy robią to na handel, którzy promują, zajmują się tym wszystkim, promują miasto [...] niech będą tacy ludzie. Oni są potrzebni. Oni są pomocni. Ale niech to będą prawdziwi twórcy ludowi, którzy wiedzą na czym polega ułożenie, na przykład, kwiatów w odpowiednią kompozycję.

W związku z powyższym respondentki spytano o cechy autentycznego twórcy ludowego i najczęściej pojawiały się tu wskazania na twórczość nieumotywowaną ekonomicznym zyskiem. Ponadto za autentycznych uchodzą twórcy, uznawani za ekspertów i weryfikatorów poprawnego wykonania rękodzieła, oraz wybitni indywidualiści, osoby o głębokiej świadomości warsztatu, opowiadający z pasją o swojej twórczości11. Jedna z badanych rzeźbiarek podała własną klasyfikację obecnych twórców:

Są twórcy [...] i to jest sztuka. Są twórcy nieprofesjonalni. Są twórcy ludowi zrzeszeni. Są twórcy ludowi niezrzeszeni. Jest wystawa i jest wystawa na przykład malarstwa twórców nieprofesjonalnych. To są ci, co nie mają akademii sztuki. A ci, co nie mają, a tworzą piękne obrazy, nazywa się ich profesjonalistami, choć często [...] tak się żartobliwie mówi: nieprofesjonalny profesjonalizm. Tak na zasadzie sprzeczności. Jest to profesjonalne, ale dyplomów nie mają.

\section{Podsumowanie}

Łowicka kultura ludowa (walory turystyczne) i produkty turystyczne powstałe w oparciu o jej zasoby stanowią często o atrakcyjności turystycznej badanego obszaru. Z historycznego punktu widzenia komercjalizacja kultury ludowej nie jest zjawiskiem nowym - na przestrzeni lat zmieniały się jedynie mechanizmy rynkowe, determinujące jej zakres i formułę. Na kształt obecnej kultury ludowej znaczący wpływ ma branża turystyczna i tzw. moda na folklor.

Współcześni łowiccy artyści ludowi reprezentują siedem dziedzin twórczości i koncentrują się w częściach środkowej i północnej ziemi łowickiej.

11 Objętość transkrypcji z wywiadów nie pozwala na ich pełne zaprezentowanie w niniejszym opracowaniu. 
Badania pokazały, że dzisiejsza kultura ludowa w większości nie zachowała klasycznych atrybutów. Sporadycznemu tradycjonalizmowi towarzyszy brak izolacjonizmu i wyraźny ekonomiczny motyw tworzenia. O ile na poziomie deklaracji sens twórczości ludowej ma podłoże $w$ regionalizmie (zwyczajach, obrzędach, religii), dominującą formą przekazu wiedzy i tradycji jest wciąż forma ustna (w rodzinie), to wyposażone w efekty marketingowe rękodzieło trafia głównie na rynek w charakterze turystycznej pamiątki.

System komercyjny negatywnie wpływa na oryginalność rękodzieła i autentyczną twórczość ludową $\mathrm{w}$ ogóle. Indywidualne warsztaty (i tak malejącej liczby autentycznych) twórców ludowych powoli są wypierane przez tzw. manufaktury ludowe i nielegalną działalność (wykorzystującą luki $\mathrm{w}$ zakresie prawa autorskiego). Powstałe w ten sposób wyroby mają niewiele wspólnego z prawdziwą sztuką ludową - łamią kanon wzorniczy, są produkowane masowo i kopiowane. $Z$ drugiej strony komercjalizacja kultury na potrzeby rynku turystycznego upowszechnia tradycję, poszerza wiedzę na jej temat, artykułuje specyfikę łowickiego regionu i daje wymierne, ekonomiczne zyski samym twórcom.

\section{BIBILOGRAFIA}

BABBIE E., 2008, Podstawy badań społecznych, Wyd. PWN, Warszawa, s. 213, 352-353.

BARTMIŃSKI J., 1990, Folklor - język - poetyka, Wyd. Zakład Narodowy im. Ossolińskich, Wyd. PAN, Wrocław-Warszawa-Kraków.

BARTOSIEWICZ M., SŁOMSKA J., 2007, Łowickie - twórcy ludowi. Szlak dziedzictwa kulturowego ziemi łowickiej, Starostwo Powiatowe w Łowiczu, Łowicz.

BRENCZ A., 1996, Wielkopolska jako region etnograficzny, Wyd. UAM, Poznań.

BurszTA J., 2000, Kultura ludowa [hasło w:] Encyklopedia socjologii, t. 1, Wyd. Oficyna Naukowa, Warszawa, s. 116-118.

CHMIELIŃSKA A., 1935, Z życia Księżaków, Warszawa.

DZIAMSKI G. 1992, Szanse i zagrożenia kultury polskiej w dzisiejszych czasach, [w:] S. Golimowska (red.), Komercjalizacja w kulturze. Szanse i zagrożenia, Wyd. Instytut Kultury, Warszawa, s. 86-89.

GAJEK J., 1976, Etnograficzne zróżnicowanie obszaru Polski, [w:] M. Biernacka, B. Kopczyńska-Jaworska, A. Kutrzeba-Pojnarowa, W. Paprocka (red.), Etnografia Polski. Przemiany kultury ludowej, t. 1, Zakład Narodowy im. Ossolińskich, Wrocław, s. 143-144.

GOLKA M., 1992, Rynek a komercjalizacja kultury [w:] S. Golimowska (red.), Komercjalizacja w kulturze. Szanse i zagrożenia, Instytut Kultury, Warszawa, s. 49-53.

GuZ M., 2009, Walory krajoznawcze gminy Kocierzew Płd., mpis pracy magisterskiej, Instytut Geografii Miast i Turyzmu, WNG, UŁ, Łódź. 
GuZ M., 2011a, Kultura ludowa jako czynnik kształtujacy towicki region turystyczny [w:] J. Wojtanowicz, Ł. Zbucki (red.), Krajobraz kulturowy a turystyka, Wyd. PSW im. Papieża Jana Pawła II w Białej Podlaskiej, Biała Podlaska.

GuZ M., 2011b, Twórcy ludowi w procesie komercjalizacji kultury ludowej na potrzeby rynku turystycznego. Przykład ziemi łowickiej, mpis pracy magisterskiej, Instytut Socjologii, WE-S, UE, Łódź.

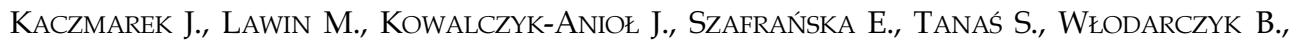
2012, Ruch turystyczny w Łodzi i w województwie łódzkim w 2011 roku, ROT Województwa Łódzkiego, Łódź.

KaczMareK J., StASIAK A., WŁOdARCZYK B., 2005, Produkt turystyczny. Pomyst, organizacja, zarzqdzanie, Wyd. PWE, Warszawa.

KŁOSKOWSKA A., 1992, O komercjalizacji w kulturze historycznie [w:] S. Golimowska (red.), Komercjalizacja w kulturze. Szanse i zagrożenia, Wyd. Instytut Kultury, Warszawa, s. 9-16.

KOŁODZIEJCZYK J., 1986, Łowicz. Dzieje miasta, Wyd. Mazowiecki Ośrodek Badań Naukowych, Warszawa.

KONECKI K., 2000, Studia z metodologii badań jakościowych. Teoria ugruntowana, Wyd. PWN, Warszawa; www. krzysztofkonecki.prv.pl.

Kurella J., 1992, Mecenat nad sztuką ludowa, [w:] S. Golimowska (red.), Komercjalizacja w kulturze. Szanse i zagrożenia, Wyd. Instytut Kultury, Warszawa, s. 58-63.

MilCZAREK K., 1997, Kultura zideologizowana - kultura skomercjalizowana. Dylematy nauki i praktyki społecznej, „Kultura i Społeczeństwo”, 3, s. 25-38.

MOKRAS-GRABOWSKA J., 2009, Możliwości rozwoju turystyki kulturowej obszarów wiejskich w Polsce, „Turystyka Kulturowa”, 1.

PRZYBYŁOWSKA I., 1978, Wywiad swobodny ze standaryzowana lista poszukiwanych informacji i możliwości jego zastosowania w badaniach socjologicznych, „Przegląd Socjologiczny”, t. 30.

ROGALEWSKI O., 1974, Zagospodarowanie turystyczne, Wyd. WSiP, Warszawa.

SILVERMAN D., 2009, Interpretacja danych jakościowych, Wyd. PWN, Warszawa.

SKIEŁCZYŃSKI S., 1995, Dawny Kocierzew, Gmina i Parafia Kocierzew, Kocierzew.

SMOLARSKI M., 1953, Łowickie, Sport i Turystyka, Warszawa.

ŚWIĄTKOWSKA A., ŚWIĄTKOWSKI H., 1996, Łowicka sztuka ludowa, Wojewódzki Dom Kultury w Skierniewicach, Warszawa.

WŁODARCZYK B. (red.), 2011, Ruch turystyczny w Łodzi i województwie łódzkim w 2010 roku, ŁTN, Łódź.

www.cepelia.pl; 19.09.2013 r.

www.zgstl.pl; 19.09.2013 r. 


\section{SCENARIUSZ WYWIADU SWOBODNEGO UKIERUNKOWANEGO Z ŁOWICKIM TWÓRCĄ LUDOWYM NT. KOMERCJALIZACJI KULTURY LUDOWEJ}

Czy zgodziłby się Pan/Pani poświęcić mi kilka minut na rozmowę? Gwarantuję, iż wywiad jest anonimowy, a wszystkie informacje objęte będą całkowitą tajemnicą i wykorzystane wyłącznie do celów naukowych.

Dopuszcza się przeformutowywanie pytań.

Czy zgadza się Pan/i na nagranie audio naszej rozmowy?

Dyspozycje i pytania:

1. W jakiej dziedzinie twórczości ludowej Pan/i się specjalizuje? (Dlaczego wtaśnie w takiej?; Co i/lub kto jest tego przyczyna??; Od kiedy Pan/i tworzy?; Od kogo Pan/i się tego nauczyt/a?)

2. Czy w Pana/i rodzinie są/były osoby, które zajmują/owały się twórczością ludową? (Kto to byt/jest?; Wjakich dziedzinach twórczości te osoby się specjalizuja/owały?)

3. Zna (lub znał) Pan/i osoby w okolicy, które również mają takie umiejętności, jak Pan/i? (Wjakich miejscowościach mieszkają te osoby?; ezw. dlaczego takich osób nie ma?)

4. Kiedy najczęściej Pan/i tworzy? (Ile czasu dziennie/tygodniowo/miesięcznie poświęca się Pan/i twórczości ludowej?; Czy sa jakieś okresy w ciąu roku, kiedy proces twórczy się nasila?; Dlaczego wtaśnie wtedy?)

5. Gdzie Pan/i tworzy? (Moge zobaczyć Pana/i warsztat $i$ sfotografować to miejsce?)

6. Dla kogo Pan/i tworzy?

7. Jak reagują na Pana/i działalność twórczą członkowie Pana/i rodziny i sąsiedzi? (Dlaczego tak?)

8. Co robi Pan/i z tym co Pan/i stworzy? (Czy w Pana/i domu/mieszkaniu wystrój stanozviq wytwory Pana/i twórczości?; Jeżeli tak, to jakie?; Moge je zobaczyć i sfotografować? ezw. dlaczego nie?)

9. Czy ma Pan/i ze swojej twórczość pieniężny zysk? (Jak średnio netto przekłada się to w skali miesiąca?; Czy posiada Pan/i wytwory, których nigdy Pan/i nie sprzeda? Co to jest?; Czy moge je zobaczyć $i$ sfotografować?)

10. Czy chciałby Pan/Pani, by ktoś kontynuował Pana/i dziedzinę twórczości? (Dlaczego?; ezv. kto to mógtby być?)

11. Czy widzi Pan/i osoby w swojej rodzinie, które mogłyby kontynuować tę tradycję? (Kto to jest?; Dlaczego wtaśnie to ta/te osoby/a?; Uczy(t)/(ła) Pan/i te osoby fachu artystycznego? ew. dlaczego, nie?)

12. Pana/i zdaniem twórców ludowych na obszarze Ziemi Łowickiej jest coraz więcej czy wręcz przeciwnie, takich osób ubywa? (Dlaczego tak jest?)

13. Czy posiada Pan/i własny strój łowicki? (Skąd/od kogo?; Czy ubiera go Pan/i? Jeżeli tak to kiedy? Jeżeli nie, dlaczego?)

14. Czy uważa Pan/i, że powinno się kultywować łowicką tradycję ludową współcześnie? (Dlaczego tak/nie?)

15. Czym różni się współczesny folklor łowicki od tego, który pamięta Pan/i jeszcze z czasów dzieciństwa? (Czy to dobrze Pana/i zdaniem, że tak się dzieje? Dlaczego?)

16. Czy tworzac korzysta Pan/i z gotowych wzorów? (Dlaczego tak/nie?; ewv. jakie sa to wzory/szablony?)

17. Czy zdarzyło się Panu/i wizyta turysty (lub innej osoby), który chciał kupić (lub zamówić) jakąś rzecz, którą Pan/i wytworzył/a? (Jeżeli tak to proszę krótko opisać takq wizytę.; Skąd/z jakich miejscozvości pochodzili turyści?; Kiedy taka wizyta zdarzyła się po raz pierwszy?; Jak wygląda "cennik ustug"?; Jeżeli, nie to czy, gdyby taka osoba się pojawita to jak by Pan/i zareagowat/a?)

18. Czy uczestniczy Pan/i w targach turystycznych lub innych wydarzeniach promujących Ziemię Łowicką, gdzie wystawia Pan/i efekty swojej twórczości ludowej? (Dlaczego tak/nie?; Jakie to wydarzenia?)

19. Czy jest Pan/i członkiem/członkinią jakiegoś stowarzyszenia twórców ludowych? (Dlaczego tak/nie?; Jakiego?; Czy zna Pan/i takie stowarzyszenia?)

20. Czy chciałby/aby Pan/i dodać coś do tego co zostało powiedziane?

Ew. dopytanie o zmienne metryczkowe, które nie pojawiły w trakcie wyywiadu.

Uwagi:

Dziękuję za rozmowę i poświęcony czas.

Ocena metodologiczna wyjwiadu:

Ocena merytoryczna wywiadu:... 